\title{
Organisation of Transboundary Cooperation, an Excellent Opportunity for Sustainable Development
}

Driton Sylqa

UNHZ, Pejë, driton.sylqa@unhz.eu

Ariana Elezaj

UNHZ, Pejë, ariane.elezaj@unhz.com

Emin Neziraj

Pejë, emin.neziraj@unhz.eu

\section{Doi:10.5901/ajis.2014.v3n2p83}

\section{Abstract}

Kosovo, Albania and Montenegro make up a triangle on the map that each of them has multiple investment opportunities in tourism. This option gives the massive picturesque and attractive mountains "Bjeshkët e Nemuna" that lies in the territory of three countries. This paper discusses the strategic planning and importance of establishing large - scale trans-boundary protected areas, those of Bjeshket e Nemuna in Kosovo, Albania and Montenegro. An overall assessment of the authors is that harmonized transboundary cooperation between three countries deemed to be necessary in order to secure a sustainable development of this destination resort. A concrete proposed model to enhance cooperation between the three respective countries gives value to this paper.

Keywords: transboundary cooperation, sustainable development, Kosovo, Albania, Montenegro

\section{Introduction}

The mountain range of Bjeshkët e Nemuna Mountains forms the natural ecological corridor connecting the whole region, but at present the integrity and continuity of habitats stretching across the state borders or corridors allowing migrations of fauna species is not yet ensured. However, there are several recent governmental initiatives on all three sides of the state border additionally confirmed by official statements, which could change the present situation and provide for the enhanced ecological connectivity and continuity of protected area network in this region.

Last year, Peja town has become the no.1 tourist destination across the globe. Through the presentation of tourist potential of its mountainous areas - on transboundary project "Ballkan peaks" that includes the triangle that connects the border, Kosovo, Albania and Montenegro - Peja was selected winner of "Tourism for Tomorrow", given by "World Travel and tourism Council". New tourist destinations are always competitive and able to gain market shares. One of the challenges of the tourism industry today is to focus more on quality than on the product, as a customer oriented strategy that makes a touristic destination more competitive. To make tourism more competitive and sustainable, it is said that innovation is a key factor to follow in order to find new solutions, services and products with the support of information and communication technologies. It is commonly believed that to make tourism a sustainable sector, it is needed a global vision and a special attention to the future of this industry, in regjional, local and national level. Effective investments should be planned and well coordinated beween counties in the region to achieve development objectives. To make tourism grow in the Balkan area, some initiatives should be taken urgently. First of all, it is necessary to accurately identify the professional skills and abilities needed by tourism enterprises and public administration and provide them, through a chain of permanent training. This is an important action to improve service quality and to satisfy the expectations of international tourism.

Some of the acts in the cultural field will focus on sustainable tourism, a concept which is still fairly new to Ballkan regional actors. Sustainable tourism tends to create the impression over the long term preservation of the natural environment, which requires the active participation of the local population and tourists for education and preservation of 
biodiversity (reforestation, protection of fauna and flora, the restoration of threatened animals, etc.).

A regional sustainable tourism of "Bjeshkët e Nemuna" requires interaction and coordination of activities of three countries of the region. These mountains have enormous natural potential with tremendous opportunities for the development of many branches of tourism. Appropriate conditions exist not only the climate, but also large complexes of forests and meadows, hydrographic wealth, natural beauty, etc. Where to build sports centers, recreation, sanatoriums, treatment centers and centers for the preparation of athletes in height diverse sea level. Rare are the mountains that have such a great wealth with an interesting fauna such are Bjeshkëve të Nemuna.

This study is focused on debate to the question, why is it important to protect natural values and cultural heritage in "Bjeshket e Nemuna", and/or "how to overcome barriers to establish a National Park at Bjeshket e Nemuna?". Furthermore, paper includes a pattern to sustainable development based on cross-border cooperation.

Thus, the purpose of the paper is:

Sensitize public opinion to strongly support establishment of national park of "Bjeshket e Nemuna" and through it promote the sustainable development of transboundary tri-lateral tourism of Kosovo, Albania, and Montenegro.

\section{Mountain tourism planning at the regional level}

Tourism planning at all levels is a key to successful implementation of tourism development and its management. The experience of many touristic zones has shown that in long-term planning, approach to tourism development brings various benefits as weel as avoids potential problems.

Planning is necessary in order to revitalize tourism and keep the economy on the right track to development in the future. Tourism should be planned at national and regional levels, which is directly related to development policy that includes structural plans, standards, ect. In the following are presented important specific favors from national and regional perspective (Krasniqi, A., Ukaj, Fatos, 2010):

$\checkmark$ Definition of the goals and policies for tourism development;

$\checkmark$ Tourism development through preservation of natural and cultural resources for present and future generations;

$\checkmark$ Integration of tourism in the overall development policy of the country and the region;

$\checkmark$ Provide a rational basis for making decisions regarding public and private sector pertaining to tourism development;

$\checkmark$ The possibility of coordinated (harmonized) development of all factors relevant to tourism;

$\checkmark$ Optimization and balance of the economic and social favors, benefits for the environment, as well as the distribution of these social benefits, which would minimize problems;

$\checkmark$ Ensure structural physical plan which is presented as a guide to the locations, type and volume of tourist development of specific tourist destination, service facilities and infrastructure;

$\checkmark$ Framing the guidelines and standards to draft specific detailed plan for developed areas;

$\checkmark$ Creating conditions for efficient implementation of tourism development policy and management thus ensuring the necessary organizational / institutional framework;

$\checkmark$ Creating conditions for effective coordination of public and private sector and intensification of efforts in tourism development;

$\checkmark$ Establishment of bases for permanent monitoring of tourism development;

\section{Location and attractiveness of "Bjeshkët e Nemuna"}

Bjeshkët e Nemuna is extensions of the Albanian Alps from the North of Albania and the province of Plava and Gucia in Montenegro. Bjeshkët e Nemuna are formed in the north peripheral part of Kosova and pull down vertically through the east and northeast in the end of Dukagjini Plain and Ibri Valley, whereas in the west they close highlands (border) between Albania and Montenegro. Uprising vertically from the Dukagjini plain, the big massifs of the BN offer a splendid view and huge tourism potential. The BN spreads on the north-south with $40 \mathrm{~km}$ longwise, whereas width does not extend over $26 \mathrm{~km}$.

The Bjeshkët e Nemuna Mountains encompass areas of unique landscape and are one of the most important regions for the protection of biodiversity in the Balkans and the whole Europe. Their name (in English: cursed mountains) best describes the character of this region, considered to be the most inaccessible mountain range in Europe and the wildest range on the Balkan Peninsula, with extremely harsh mountain environment providing for the extremely hard living 
conditions for their inhabitants. The highest peaks are Maja Jezercë (2694 m) in Albania and Gjeravica (2656 m) on the territory of Kosovo. Zla Kolata $(2534 \mathrm{~m}$ ) in Bjeshkët e Nemuna is the highest peak of Montenegro. The number of glacial ponds in this area is rare for the European mainland and can only be compared to the Alps. The proposed "Bjeshkët $\mathrm{e}$ Nemuna Mountains" transboundary protected area can involve as many as six protected areas (three national parks of IUCN Category II and three regional parks of IUCN Category V) and encompass the total territory up to some 205'174 ha, which will then make it the one of the largest protected areas in the South Eastern Europe.

Feasibility study (UNEP-Vienna) provides a brief overview on the local transboundary context for cooperation in the region, e.g. border context, socio-economic context, the state of the environment of the region and potential threats. The study describes existing legal and administrative frameworks and compares the development of protected area networks in particular countries, provides a brief overview of the natural values and protected areas of the region, and initiatives aimed at improving the connectivity and continuity of protected area network. Finally, the study suggests priorities for biodiversity conservation and transboundary cooperation in the region, and concludes with the analysis of different opportunities and challenges for transboundary cooperation in the proposed transboundary protected area "Bjeshkët e Nemuna Mountains" (Feasibility study GOK, 2003).

\subsection{The legal framework for proclamation of national park}

Legal basis for declaring the Accursed Mountains National Park lies in the Law on the protection of natural values and values created by human work environment ("KOG " 39/88). Under this law, the National Park is the region with preserved natural values, created and esthetical which are important for cultural heritage, educational, scientific, and touristic purposes. National Park may be allowed only with activities that do not jeopardize the source of flora and fauna, hydrographic values, geomorphological, geological, cultural and landscape values of the National Park as well as actions that natural balance is maintained or established. Economic activities and other activities in the territory of the National Park should be exercised only in accordance with the programs of the National Park.

For the first time in Kosovo, environment may be protected by legal frameworks conform to the International Convention for the protection of the environment through criminal law. Under this law, our country respected the principles and requirements of the International Convention on the protection of the environment (European Council, 1998).

\subsection{Present barriers for the announcement of National Park}

It is unavoidable for Kosovo to have such a good area and not to have it in the protection. Also if Kosovo wants to join the $\mathrm{EU}$, it is necessary to fulfil the directive where $10-15 \%$ of the territory of the country has to be protected area. On of the critical barriers to proclamation of NP is strongly rejection of forestry inhabitants. It is most likely that "people of the forestry have a fear for losing the pastures and that they could not cut the tree" and "they somehow act through the politicians" and his opinion is that this issue is stocked for some period. To add in the low more specific about the boundarys which will define a green area and this will specify the three zones with the restrictions, and to become preliminary which is protected zone and which zone will be available for the inhabitants and the pastures so this way we will eliminate phobias of the designation for the protected area. Inhabitants and the settlements in BN territory are divided in: permanent inhabitants and temporarily inhabitants. Those permanent settlements are for the people who live in this area and temporary which are using sports terrain and hotels. In post war period there has been many illegal hotels and housing constructions done, which has degraded this area, and this place need quickly decision of the parliament or other forms which can help to save this area from the environmental hazards (UNEP, 2010).

\subsection{Long term vision for Bjeshket e Nemuna Mountains}

The second trilateral stakeholder meeting in the proposed transboundary protected area Bjeshket e Nemuna Mountains was held in Shkodra in September 2013. The conference participants, including the representatives of regional organizations, discussed and agreed on the need for long-term thinking. The present joined forces, shared information and pointed out the importance of factors common for the area: internet access and improved border crossings. During the last year, B3P members led a highly successful cross-border trek which took place in all three countries that the proposed protected area encompasses. The B3P had a chance to reiterate its own priorities: environmental thinking, the protection of the diverse culture of the region, and the promotion of economic development with a focus on sustainable 
tourism. (Tod Walters, 2012).

\section{Future Perspective for Bjeshket e Nemuna}

According to the technical definition of International Union for the Conservation of Nature (IUCN) 2001, Peace Parks are defined as: trans-boundary protected areas that are for mally dedicated to the protection and maintenance of biological diversity, and of natural and associated cultural resources, and to the promotion of peace and cooperation (UNDP, MDG, 2005).

All current initiatives aiming at the extension of already existing protected areas and establishing new large-scale protected areas are indispensable for protecting the best preserved natural areas of the Balkans. The region still has the high potential for protecting even more natural areas of high biodiversity values than those designated until today. This is only possible if there is a fast intervention with an integrated approach and close cooperation among, especially, municipalities under which the proposed territories for the cross-border Balkan Peace Park are residual own task (under environmental and spatial planning) in the menu of LSG of these municipalities which derive from European Charter of Local Self Government or adopted to its guidelines and principles. In this case, "we are speaking of horizontal cooperation where municipalities work together, share tasks, and make alliances and joint actions within a country as well as with municipalities outside the border, especially where their territories and issues such as environmental and development coincide." (Shala, D., 2006).

In these cases, municipalities enter into cross-border cooperation without need of approval from the central governments, or the need for respective government's toprecede with such actions through foreign ministries, governors or presidents which is much complicated, long and bureaucratic process. However, a good political will and support is required and municipal cross-border cooperation can and shall be staring point (after civic society in the Balkan peace Park) and instrumental to influencing their regional and central authorities to not only for support, but to show this by necessary institutional adjustments and relations in the higher levels, e.g. respective ministries of environment, culture, tourism, economy, etc. come up with cross border regional cooperation and adopt such practices as part of their national legislation, strategies and action plans in concerned areas (Radoniqi, L.2007).

\subsection{The added value and possible benefits}

Establishment of the cross-border Peace Park Project among Albania, Montenegro and Kosovo, would imply the following:

$>$ International peace parks possess great potential as a tool for cross-border cooperation, for environmental conservation, sustainable development, and livelihood creation-if they are created and managed with the participation of a broad range of stakeholders from all affected countries;

$>$ New local and regional unique identity and values vs. potentially will attract international funds, as well as government and private funding;

$>$ Increase of cultural and socio-economic cooperation and exchange in the region leading to sustainable development based preservation of diverse natural and cultural heritage, enabled by horizontal cooperation among municipalities and NGOS, as mentioned above;

$>$ Long lasting peace and stability in the western Balkans, which will be an added value to its regional integration into EU;

> It is important to coordinate efforts to develop peace parks at the ecosystem level;

$>$ Short- and long-term employment opportunities linked to the peace park initiative can help shift incentive structures for local communities towards conservation as a viable land-use option and can consolidate public support for the establishment of a peace park;

$>$ Use of an integrated multi-track approach can increase the chances of success and spur the development of a wide range of related programs, projects, and initiatives on multiple levels.

$>$ Timing is critical in the development of an international peace park because a park cannot be created unless the principal state decision makers are ready and the concept is embraced by a critical mass of stakeholders;

$>$ Effective and functioning National Parks must exist in each country, and be contiguous, in order to be functionally linked together to form a transboundary protected area, which can then be dedicated as an International Peace Park. 


\subsection{Transboundary cooperation and livelihood creation through coordinated environmental conservation}

A prime example of the use of the multi-track approach is the proposed Balkans Peace Park in Albania, Montenegro and Kosovo. Due to the dramatically different relationship that Montenegro and Kosovo have with their former state of Serbia, an international peace park seem to be extremely challenging, making it possible to employ a multi-track approach just below the highest levels of government, where political constraints are not as significant.

Engaging with the multi-track approach for the Balkans Peace Park has created a collaborative community comprised of the Mayors of the Municipalities where the proposed peace park would be located, the government Ministries for Environment, Tourism and Development, the international development agencies of foreign countries, individuals from the U.S. Peace Corps and the U.S. and British Embassies, local NGO leaders from Albania, Montenegro, and Kosovo, and local people who reside within the proposed peace park area.

Many different actors and projects yield a variety of opportunities for livelihoods creation - from small-scale sustainable development initiatives to large-scale biodiversity surveys to even larger infrastructure development projects. The loosely knit coalition of stakeholders is growing closer together over time capitalizing on one of the under recognized benefits of collaboration - the more people collaborate, the better and more efficient and effective the collaboration becomes over time. Almost a decade since the Balkans Peace Park Project began in 2001, there is now a community of stakeholders committed to cross-border cooperation on issues of environmental conservation, natural resource management, and sustainable development. These stakeholders are all engaged with one other and working towards many of the core goals of creating an International Peace Park. It is crucial to note that an infinite amount of multi-track diplomacy can occur, but until the diplomacy generates a critical mass of citizens in many different capacities putting pressure on the Governments involved, or unless it involves Track 1 actors, there can not be a formal "official" declaration of the Peace Park's existence. Multi-track diplomacy while broad in depth, is limited in scope of official national efficacy, particularly when engaging issues of sovereignty. For the International Peace Park to successfully make the transition from multi-track collaboration on a "proposed peace park," involving a number of different stakeholders at a number of different levels, to an "Official" International Peace Park, actors at the Track 1 level need to recognize the park in an "official diplomatic declaration" in a MOU or formal Treaty (UNEP, 2010).

\subsection{The matter of status of the National Park in each country}

Major challenge that is preventing the formal declaration of the proposed Balkans Peace Park is the status of the National Parks in each country: Theth National Park in Albania, Prokletia National Park in Montenegro, and yet the proposed Bjeshket e Namuna National Park in Kosovo. You cannot have an International Peace Park if you do not have existing, functioning, contiguous National Parks in all three countries to link into a transboundary Peace Park.

In Albania and Montenegro, the respective areas has been already declared National Park, but has been critiqued by many as a "paper park" existing only in law and not in reality, without any infrastructure, understood or demarcated boundaries, or management structures. Whilast, in Kosovo the current initiative to formally gazette Bjeshket a Namuna National Park system has been defeated two times in the past few years, and if defeated a third time will be forced by the Kosovar constitution to face a 20 year moratorium before it can be proposed again. The reason that the bill failed the previous two times is directly related to the knowledge of the local people regarding what the benefits and the multi-use regulations of the National Park would be. Past proposals failed to inform local people of these benefits, and they were under the misconception that creating a National Park would displace them from their land and mountain homestead, to which they have territorial family or clan claim, but not a legal title; as well as remove traditional grazing rights for livestock. Until all of these challenges on the National level can be addressed, there can be no functioning National Parks to link together into an International Peace Park.

Even when national level issues can be addressed, the hurdle of the official Track 1 political context with all of its layers of international diplomatic intrigue remains-from the relationship with Serbia, to EULEX in Kosovo maintaining its capacity building presence, to the competition to achieve EU Accession status and eventually full membership. All of these issues make it politically unlikely that an international agreement in the form of a Treaty to formally create an international peace park is feasible within the current context. However, the political situation changes so rapidly that there may be a ripe moment in the future when the multi-track approach will build a critical mass of support and be applied effectively during the right window of opportunity. The Balkan Peace Park Project has been effective, working at many different levels of society and politics in the region, but has yet to muster the cache to influence Track 1 diplomacy, and international policy (Tod Walters, 2012). 


\section{The neccessity of transboundary coordination}

Resulting from harmonized or coordinated management practices in a transboundary protected area, protection of natural habitats located across or close to the state border should be enhanced, the migration of speciesacross the state border should become uninhibited, continuation of natural evolutionary processes across the state border should be ensured, and common threats to nature and transboundary environmental hazards jointly identified and controlled.

Implementation of the project requires the political determination of three border governments to establish contemporary mountain tourist centers, which requires strong government support. Investments must be oriented to the development of sites associated with better infrastructure networks and have rich potential resources.

The added value and possible benefits for all involved countries deriving from the establishent of the proposed transboundary protected area are that the trilateral or even quadrilateral transboundary cooperation in this region would largely facilitate:

$>$ Achievement of their nature protection and biodiversity conservation objectives;

$>$ Mitigation of the present threats to environment and nature of the region;

> Promotion and implementation of sustainable development at regional level;

$>$ Establishing a long term transboundary cooperation mechanism serving the local stakeholders;

\subsection{Recommended action plan}

Due to the fact that the main tourist attractions of this transboundary region are the exceptional landscape and natural values of the Bjeshkët e Nemuna Mountains, the development of sustainable tourism in the region would require close cooperation of the tourist services providers with the authorities of the protected areas in the region.

It should be noted that the successful achievement of several priorities from the below tentative priority list is not feasible in short term, and would require both intensive preparatory works and consultations within all concerned countries, and trilateral consultations on ministerial level, as well as declaration of the whole zone as national park:

* The need for developing a harmonized spatial design and internal functional zonation of the proposed transboundary protected area on each side of the state borders;

* A public awareness campaign involving local non-governmental organizations and enhanced consultations with the local communities should be undertaken well in advance to public hearings;

* Improvement of road infrastructure, with the objective to establish road connections through the mountains across the state borders, and enhance direct personal contacts between the transboundary cooperation partners;

* Promotion and marketing of the local organic food and handicraft products;

* Clarification of the border regimes and status of border crossings in the mountains, with the objective to facilitate establishment of cross-border tourist hiking trails;

* The presence of representatives of the National Park in three countries, and in particular of the protected area administrations from Albania National Parks;

* National Park could largely catalyze the positive attitudes of the local municipalities towards developing transboundary cooperation in the proposed project where the planned Bjeshkët e Nemuna National Park would be the key partner on the side of Kosovo;

* Consultations in Kosovo with relevant stakeholders for the designation of the planned Bjeshkët e Nemuna as a National Park should officially be launched by the respective Ministry in cooperation with other relevant ministries, with Kosovo Forest Agency, with the authorities of the local municipalities of Pejë, Deçan, Istog and Gjakovë, the experts from the University of Prishtina and University of Haxhi Zeka could largely facilitate such consultations;

* The newly established protected area administrations would require operational and professional/technical capacity building, which could include some common trainings, study visits or organizing joint thematic seminars gathering experts from all involved countries;

* The development of harmonized management plans is possible, but subject to necessary consultations between relevant authorities and scientific institutions of all countries concerned;

* Intensive exchange of information, scientific data, methodological experience between relevant authorities and scientific institutions of all countries concerned are indispensable;

* Development of feasibility studies for the planned new protected areas in the region of the proposed 
transboundary protected area;

- Reach a signed agreement on cooperation between respective countries and providing a follow up;

* The potential agreement should clearly state the common vision, priorities and fields of work for cooperation in the proposed transboundary protected area, allocate duties and responsibilities among different cooperation partners, delegate powers and designate authorities mandated to coordinate transboundary cooperation, authorize allocation of the part of the state budget funding for common transboundary activities. A possible agreement should also refer to the socio-economic context and well-being of local communities, linking such with the protection of common natural and cultural values. Last, but not least, such agreement should later officially be communicated to local stakeholders on each side of the state border;

* Since the cooperation has so far been developed mostly on informal basis, it is highly recommended that future meetings should be organized formally, should be properly recorded and documented, ect;

* It should be recalled that the scarce network of roads and border crossing points in the mountains of Bjeshkët e Nemuna, could be a factor seriously impairing the frequency of the visitors. Hence, each country should be responsible to invest in road crossing borders network in a common project, particularly in directions: Pejë Plav, Deçan-Plav, Plav-Shkodër;

\section{Conclusion}

Until Bjeshket e Nemuna in Kosovo became National Park, and unless all mentioned challenges are being addressed on the national level, there can be no functioning National Parks to link together into an International Peace Park.

Should the above mentioned unique landscape, natural and recreational values of the region significantly deteriorate in result of e.g. uncontrolled development or illegal practices - the present high tourist attractiveness would immediately decrease. In result no new visitors would be attracted to come to the Bjeshkët e Nemuna Mountains, while some part of the current visitors to the area may decide to chose other holiday destinations, where adverse effects of human economy on environment, landscape and nature are either none or better prevented, providing for better quality of recreation. The mountains of this region are indeed highly attractive for mountain trekking and skiing, but there are many other mountain ranges in Europe providing similar recreation opportunities, often paired by other attractions

Other potential benefits of transboundary cooperation, in particular those for sustainable local economic development, could be more appealing and attractive for the local communities, thus potentially raising local support for establishing a transboundary protected area, perceived as a tool for improving the life standards and well-being of the area inhabitants

Even though the Balkans Peace Park still remains a proposed park, steps towards formally establishing the park continue to be taken, while stakeholders prepare for the proper moment to apply pressure at the national levels for the formal creation and dedication of the Balkans Peace Park. Lessons from the Balkans can serve others involved in transboundary conservation efforts around the world, allowing them to learn from, adapt, and apply these lessons in their own local context. And of course, the Balkans Peace Park Project (B3P) continues to scour the literature from Peace Studies, Environmental Studies, Borderlands, Anthropology, and other disciplines, in order to apply lessons learned elsewhere in Albania, Kosovo and Montenegro, and make the dream of that formal declaration a reality.

\section{References}

State Agency of Environment and Forests, Environment Report, Albania 2007;

Council of Europe, Committee on the Environment, Regional Planning and Local Authorities, Strasbourgh , 1998;

Ene S., Baraitaru M., Sustainable Development Strategies in Domestic and International Tourism, 2010;

Feasibility study for proclamation of Bjeshkët e Nemuna as a National Park, Prishtinë, 2003;

KINEP, MESP, Kosovo, Reasoning study for announcement of the territory of bjeshkët e nemuna as a national park, Prishtinë, Web site: http://www.ks- gov.net/mmph/

Krasniqi , Armand , Ukaj , Fatos, Organizations and Management in Tourism Destinations , 2010;

Ministry of Environment and Spatial Planning of Kosovo - KEPA. State of Environment Report 2006 - 2007. KEPA, Prishtinë 2008;

MAFRD, Kosovo, web site: http://www.mbpzhr-ks.org/;

Radoniqi Lendita, Bjeshket e Nemuna, master thesis, 2007; tut

Radoniqi, L. Bjeshkët e Nemuna - future prospects for a national park. Blekinge Institute of Technology, Karlskrona, 2007;

Research on the reasonableness of the declaration of the territory of the Accursed Mountains National Park , 2003;

Shala D., (2007). Course Paper European Master on Comparative Local Development, web site: http://www.mastercode.unitn.it/

UNEP, Feasibility study on establishing a transboundary protected area, "Bjeshkët e Nemuna Mountains" Vienna, 2010; 
Walter Tod., The Evolution of the Balkans Peace Park Project, Institute for Environmental Diplomacy and Security, University of Vermont, 2012;

http://www.telegrafi.com/lajme/jamajat-e-ballkanitja-fut-pejen-ne-harten-boterore-te-turizmit-2-28559.html; http://www.wttc.org/tourismfortomorrow/; 